\title{
Export oriented Ornamental Fish Industry in Sri \\ Lanka
}

By

P. U. I. Perera

M. Sc. In Fisheries and Aquatic Resources Management Faculty of Graduate Studies University of Sri Jayewardenepura May 2009. 


\section{Declaration I}

The work described in this thesis was carried out by me under the supervision of Dr.R. R. M. K. P. Ranatunga and Dr. H. M. Palitha Kithsiri and a report on this has not been submitted to any University for another degree.

\section{P.U. I. Perera}

National Institute of Fisheries and Nautical Engineering,

Crow Island,

Mattakkuliya,

Colombo- 15.

Sri Lanka. 


\section{Declaration II}

We certify that the work of P. U. I. Perera on Export Oriented Ornamental Fish Industry in

Sri Lanka for the degree of M.Sc. in the Faculty of Science at University of Sri Jayewardenepura.

We feel that the candidate's work is complete and suitable for submitting to the University for the purpose of evaluation.

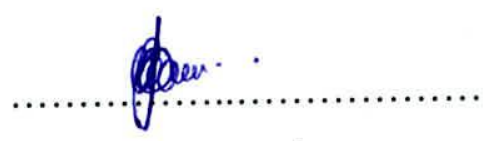

Internal Supervisor,

Dr: R. R. M. K. P. Ranatunga.

Senior Lecturer,

Department of Zoology

University of Sri Jayewardenepura,

Nugegoda.

Sri Lanka.

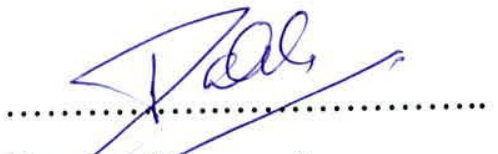

\section{Externar Supervisor,}

Dr: H. M. Palitha Kithsiri.

Head of the IARAD,

NARA, Crow Island,

Mattakkuliya,

Colombo-15.

Sri Lanka. 


\section{Export oriented Ornamental Fish Industry in Sri Lanka}

By

\section{P. U. I. Perera}

Thesis submitted to the University of Sri Jayewardenepura for the award of the degree of Master of Science in Fisheries and Aquatic Resources Management. 


\section{Acknowledgements}

I express my deepest gratitude to my supervisors, Dr: Kamal Ranatunga, University of Sri Jayewardenepura and Dr: H. M. Palitha Kithsiri of the National Aquatic Resource Research and Development Agency for their encouragement and guidance throughout the course of study. I would like to extend my sincere gratitude to Dr Ajatha de Alwis, Senior Lecturer, Department of Zoology, University of Sri Jayewardenepura, for her invaluable comments to substantially improve this manuscript. I also wish to thank M.Sc. Course Co-ordinator Dr. Nissaka De Silva of the University of Sri Jayewardenepura for his assistance to complete this dissertation.

I am grateful to Captain S. K. S. Jayasinghe, former Director General of the National Institute of Fisheries and Nautical Engineering for encouraging and giving me the opportunity to study further and arranging the funds from the NIFNE.

I also thank to all exporters and farmers in Gampaha and Colombo districts for providing me necessary information.

I wish to thank Mrs. Sandamalie, Incharge of the ornamental fish exchange of NAQDA and Mr. P. Jayasooriya, Senior Statistician and other staff of the same division of the DFAR for their corporation and giving me the important data.

I also wish to thank the staff of the Sri Lanka Customs and Export Development Board for providing me the data on export and import of ornamental fish.

I extend thanks to my wife Gayani, daughter Benashi and son Bimsara for their patient during the study period enable for me to complete the dissertation work in time. 


\begin{abstract}
This project was to study the present status of export oriented ornamental fish industry in Sri Lanka with a view to identify constraints faced by the farmers and exporters and recommend remedial measures for the sustainable development of the industry. Fifteen of the major exporters from Colombo and Gampaha Districts were interviewed during the study.
\end{abstract}

It was observed during from the study that the main problem in the ornamental fish farming industry is the undercut of ornamental fish prices. This undercut process adversely affects the industry. Lack of low cost nutritious feed for fish is another problem in the ornamental fish farming industry. Generally feed cost contributes about $50 \%$ of the operational cost. Therefore, to sustain the industry, research organizations should focus their research to formulate low cost nutritious feed for ornamental fishes. Another problem in the industry is bad packing practices during transportation of fishes. Freight charges mainly calculated base on the weight of the packing boxes. Hence, more fish have to be packed in a bag to minimize the transport cost and therefore, research should be focused on improving packing conditions. The other problem the industry face today is the lack of high quality brood stock for ornamental fish breeders. Therefore, it is recommended that relevant government institutes should discuss the issues and challenges responsible for the development of this sector with fish exporters and farmers and make necessary arrangements to overcome those constraints for the sustainable development of ornamental fish industry in Sri Lanka. 


\section{Table of contents}

Chapter

Page

Declaration I $\quad$ i

Declaration II $\quad$ ii

Title page $\quad$ iii

Acknowledgements iv

Abstract $\quad \mathrm{V}$

Table of contents vi

List of figures $\quad$ ix

List of tables' $\quad \mathrm{x}$

1 Introduction 1

1. 1 Background 1

1. 2 Importance of ornamental fish industry in Sri Lanka 2

1. 3 History and culture of ornamental fish industry in Sri Lanka 3

1. 4 Objectives 5

2 Literature Review 6

2.1 Trends in the freshwater aquarium trade 6

2.1.1 Freshwater ornamental fish 6

2.1.2 Marine fish and Invertebrates 6

$\begin{array}{ll}2.2 \text { Endemic fish } & 10\end{array}$

2.2.1 Endemic fish species restricted for export 12

2.2.2 Endemic fish species prohibited for export 12

2.3 Present status of ornamental fish export 13

2.3.1 Training and education 13

2.3.2 International of ornamental fish trade $\quad 14$ 
2.3.3 Contribution of Asian countries to global ornamental fish trade 16

2.3.4 The main importing countries 16

2.3.5 The main exporting countries and their contribution $\quad 17$

2.4 Institutional involvement 18

2.4.1 Aquarium ornamental fish industry Consistency 19

2.5 Opportunities for exporters 19

2.6 Favourable factors for the industry in Sri Lanka 21

3 Methodology 23

3.1 Study area 23

3.2 Methods of data collection 23

3.3 Data collection from ornamental fish farms 23

3.4 Data collection through Governmental and Non-governmental $\begin{array}{ll}\text { Organizations } & 24\end{array}$

4 Results $\quad 25$

4.1 Present status of fish exports 25

4.1.1 Number of ornamental fish exporters 25

4.1.2 Species contribution of freshwater ornamental fish exports 25

4.1.3 Importance of exotic ornamental fish in the industry 27

4.2 Present status of fish farmers 28

4.2.1 Present values of fish export 29

4.2.2 Main exporting countries $\quad 35$

4.3 Ornamental fish marketing channels 35

4.4 Exporting procedure of ornamental fish $\quad 37$

4.5 Local market in ornamental fish industry $\quad 37$

4.6 Operational cost in export ornamental fish industry 38

4.6.1 Exported value of restricted ornamental fish 2004- $2008 \quad 39$

4.6.2 Freshwater wild-caught fish species $\quad 39$ 
4.7 Nursing and larval rearing of fish species $\quad 41$

4.7.1 Parameters of breeding $\quad 42$

4.8 Packing facilities of ornamental fish industry 42

4.9 Constraints in the industry $\quad 47$

4.9.1 Long term constraints $\quad 47$

4.9.2 Short -term problems faced by exporters $\quad 49$

4.10 Methods to make a real market of the industry 49

5 Discussion 51

$\begin{array}{ll}\text { References } & 57\end{array}$

$\begin{array}{ll}\text { Appendices A-1 } & 60\end{array}$

$\begin{array}{ll}\text { Appendices A-2 } & 64\end{array}$ 


\section{List of the Figures}

Figure

1. World trade in ornamental fish: Share of main exporting countries

2. World trade in ornamental fish: Share of main importing countries

3. Increase in export value of ornamental fish (1990-2008)

4. Import value of ornamental fish, 2005-2008

5. Monthly percentage exports of marine fish 22

6. Monthly percentage exports of freshwater fish 22

7. Percentage export contribution of fish species during the study period 26

8. Monthly export variation in freshwater fish within the study period 26

9. Glass tank quarantine 29

10. Fish conditioning tanks 29

11. Major export freshwater ornamental fish species 31

12. Major export marine ornamental fish species 32

13. Flow- chart to show ornamental fish marketing channel 36

14. Exporting procedure of ornamental fish 37

15. Fish species contribution to the local market 38

16. Exported value of restricted ornamental fish 2004- 2008 39

17. Major export endemic freshwater ornamental fish species 40

18. Flow- chart of fish packing steps and procedures 43

19. Fish packed in double polythene bags 44

20. Asian style shipping box (bottom) and Styrofoam insert (top) 46

21. Air-condition truck 


\section{List of Tables}

\section{Table}

1. Marine fish species with high export demand

2. Marine invertebrate species with high export demand

3. Marine fish species prohibited from export

4. Marine fish species restricted from export

5. Restricted freshwater fish species identified for exported

6. Endemic freshwater fish species prohibited for export

7. Institutional involvements

8. Main exotic freshwater fish species dominating the market

9. Capacity level of farmers

10. Facilities available with exporters

11. Main exporting fish species and their average

12. Methods of collecting fish for export 30

13. Methods of receiving export orders 33

14. Details of the shipments 34

15. Main exporting countries and export percentage 34

16. Operational costs as percentage in export ornamental fish industry

17. Main wild-caught freshwater fish species that are exported from Sri Lanka 38

18. Nursing and larval rearing of some fish species

19. Parameters of breeding for some freshwater fish species

20. Packing capacity of ornamental fish species 


\section{Chapter 1}

\section{Introduction}

\subsection{Background}

Ornamental fish industry in Sri Lanka presently earns substantial foreign exchange (Rs. 972 million. in 2008) (EDB, 2009). However, this level of achievement can be considered as modest compared with the opportunities available in a rapidly growing global market of over US\$ 3 billion for ornamental fish and related accessories in which the local share is negligible. Therefore, this industry can be expected to contribute far greater advantage to Sri Lanka's economy than at present, by harnessing the vast and varied resources available in the country.

Sri Lanka has a tropical climate, in many areas of this country suitable for aquarium industry. Aquarium fish industry can be categorized into four groups based on medium as follows;

\section{Tropical marine species}

Tropical freshwater species

Brackish water species

Cold water species

There are 111 freshwater fish species in Sri Lanka (Pethiyagoda, 1991). This includes 21 exotic species, which have been introduced either by intension or accident during the last century. There are 44 endemic fishes record in Sri Lanka (IUCN, 2007). As far as the ornamental fish trade is concerned, 35 popular species are exported in the market. Ten species dominate the global freshwater ornamental fish trade. Neon tetra (Paracheirodon innesi) and guppy (Poecilia reticulata) accounts $60 \%$ of the export trade. Marine ornamental fishes contribute $20 \%$ and brakish water fishes contribute about $05 \%$ of the export trade. 
In Sri Lanka exported freshwater live fish are either bred and cultured in captivity and collected from wild. Most of prohibited endemic fish species which have high demand in the world ornamental fish trade are collected from wild. Live freshwater animals include finfish and some crustaceans while marine exports include both finfish and invertebrate species.

\section{2 Importance of ornamental fish industry in Sri Lanka}

\section{Additional income generation}

Many people engage in several employments. But they are possible to combine with the industry by using their rest of time for earning additional income.

\section{Self employment opportunities}

Many people are engaged in this industry as a self employment. Employment opportunities have greatly increased and as a result, many youngsters now making a living by collecting marine and inland water fish, invertebrates from the wild for export and local market.

\section{Land usage}

In Sri Lanka more lands are abundant. Lands which cannot be used for agriculture or other purpose could be utilized for ornamental fish farming.

\section{Foreign income generation}

This industry has become an important foreign income generation in Sri Lanka by earning about 8.7 million US\$ annually.

\section{Land suitability}

Most of the areas in Sri Lanka are suitable for ornamental fish farming as there is good quality water, favourable climate. 


\section{Minimum investment}

This industry can be initiated with minimum investment and after they can develop gradually.

\section{Minimum environmental pollution}

Ornamental fish farming can be done with minimum environmental pollution unlike other aquaculture industries.

\section{Minimum space}

Ornamental fish farming can be done with minimum space.

\section{Breeding and culture technologies}

Because of the institutional involvement in giving scientific and technological knowledge, breeding and culture technologies are available for many high demand species among the fish farmers.

\section{Minimize the risk of human}

Ornamental fish keeping known to helps to minimize the risk of human heart diseases as well as aesthetic purposes.

\section{3 History and culture of ornamental fish industry in Sri Lanka}

Ornamental fish industry in Sri Lanka has a long history and has started with small scale outlets in homes in cities. Ornamental fish export industry in Sri Lanka was initiated in 1930 's and the industry was totally based on export of wild collected fish, particularly freshwater species (Axelrod, 1960). There were few number of exporters in Sri Lanka. The first commercial aquarium was started in 1952 in Colombo (Rodney, Jonklass, 1988). This industry was commercialized by few medium scale and large scale farmers about 50 years ago and it has now developed into a lucrative industry affording profit and employment to many (Kuruppu, 1998). The export aquarium trade expanded gradually from the 1950 s as 
more exporters began to operate from Colombo. As air transport got more popular and less costly, live aquarium fish for export took to the skies. Commercial level ornamental fish exports started in 1980's (Mee, 1991).

Sri Lanka presently earns about 8.7 million US\$ from the aquarium trade and export ornamental fishes to over 40 countries (EDB, 2007). In Sri Lanka, there are about 20 large scale companies engage in exporting ornamental fish in to various countries, throughout the world (EDB 2007). Aquarium fish industry in Sri Lanka initiated around Colombo which is the commercial capital as a result of establishment of zoological garden in Dehiwala (Jonklaas, 1989). The industry established at such a scale that it continued to grow and finally it developed to an export market. As a result of overcrowding, high labour cost and lack of land for overgrowing system, the large scale growers started to move out to rural areas of the dry zone in the country. Presently the out growing systems are distributed in western, north central, north western and central provinces of Sri Lanka (Weerakoon, 1997).

Exporters assist the contract growers by supplying fish fry, feed, chemicals and basic technology for growing aquarium fish and to buy back system when the fish ready for export market. 